\title{
A pszichológiai jóllét szociodemográfiai korrelátumai, kapcsolata a big five vonásokkal és az optimizmussal
}

\author{
NAGY HENRIETT* - GYURKOVICS MÁTÉ \\ Eötvös Loránd Tudományegyetem, Pedagógiai és Pszichológiai Kar, \\ Pszichológiai Intézet, Budapest
}

(Beérkezett: 2016. február 1.; elfogadva: 2016. május 3.)

Elméleti háttér: A pszichológiai jóllét többtényezős modelljét Ryff alkotta meg 1989-ben. Korábbi kutatások rámutattak arra, hogy a pszichológiai jóllét az extraverzióval pozitív, a neuroticizmussal pedig negatív irányú összefüggést mutat, továbbá igazolták a pszichológiai jóllét és az optimizmus közötti kapcsolatot. Cél: Jelen tanulmány arra keresi a választ, hogy milyen mértékben alkalmasak az ötfaktoros elmélet személyiségvonásai a pszichológiai jóllét szintjének előrejelzésére magyar mintán (figyelembe véve a demográfiai tényezők hatását is), illetve, hogy az optimizmus képes-e bejósolni a pszichológiai jóllét szintjét a big five dimenziók kontrollálása után is. Módszer: Keresztmetszeti vizsgálatunkban 314 felnőtt (63,7\% nő; átlagéletkor: 29,5 év, SD =10,96 év) vett részt. Mérőeszközök: szociodemográfiai kérdések, Big Five Kérdőív, Pszichológiai Jóllét Skála, Életszemlélet Teszt. Eredmények: Az alábbi szociodemográfiai változók mutattak kapcsolatot a pszichológiai jólléttel: az anyagi helyzet; a jelenlegi lakóhely; az apa iskolai végzettsége; és az anya iskolai végzettsége. A személyiségváltozók közül a diszpozicionális optimizmus erôs, pozitív irányú együttjárást $(\mathrm{r}=0,61 ; \mathrm{p}<0,001)$ mutatott a jóllétszinttel, a big five dimenziók pedig legfeljebb közepes mértékú összefüggést jeleztek $(r=|0,27|-|0,45|$; $p<$ 0,01). A bináris logisztikus regresszió elemzés eredményei alapján a big five személyiségvonások mind szignifikáns hatást gyakoroltak a jóllét szintjére a szociodemográfiai változók szinten tartása utána is - és e hatás valamennyi dimenzió esetében pozitív, a neuroticizmust leszámítva (Nagelkerke-féle $R^{2}=59,9 \% ; \chi^{2}(17)=156,35 ; p<0,001$ ). Az eredmények szerint továbbá az optimizmus önálló $(\mathrm{OR}=4,32, \mathrm{p}=0,014)$, a big five dimenzióktól független magyarázóerővel bír a jóllétszint alakulása tekintetében (Nagelkerke-féle $\left.\mathrm{R}^{2}=61,7 \% ; \chi^{2}(18)=162,75 ; \mathrm{p}<0,001 ; \Delta \chi^{2}(1)=6,39 ; \mathrm{p}=0,011\right)$. Következtetés: Jelen kutatás egy újabb bizonyíték azon kutatások sorában, amelyek azt demonstrálják, hogy a személyiség lényeges szerepet játszik a pszichológiai jóllét alakulásában. Az eredmények azt is sugallják, hogy az optimizmus önálló, a big five dimenzióktól független magyarázóeróvel bír a jóllét szintjének alakulása tekintetében.

Kulcsszavak: pszichológiai jóllét, szociodemográfiai tényezők, személyiségvonások, big five dimenziók, optimizmus

\footnotetext{
* Levelező szerző: dr. Nagy Henriett, Eötvös Loránd Tudományegyetem, Pedagógiai és Pszichológiai Kar, Pszichológiai Intézet, 1064 Budapest, Izabella u. 46. E-mail: nagy.henriett@ppk.elte.hu
} 


\section{Bevezetés}

A jóllét elméleti megközelítésével kapcsolatban két hagyomány különíthető el (Ryan \& Deci, 2001). A hedonikus megközelítés elsősorban arra fókuszál, hogy mi minden teheti kellemessé az életet, mi járulhat hozzá a szenvedés elkerüléséhez és az örömök maximalizálásához. Az eudaimonikus megközelítés pedig a jóllétet a szelf-realizáció és növekedés terminusaiban írja le, e szerint az önismeret (erősségek, gyengeségek, értékek, célok ismerete) szükséges ahhoz, hogy elérjük az eudaimonia állapotát, amely Arisztotelész szerint a humán létezés végső célja. A pozitív pszichológia jelenkori megközelítésében a hedonikus jóllét hagyomány a szubjektív jóllét koncepciójához (Diener, 1984), az eudaimonikus jóllét pedig a pszichológiai jóllét modelljéhez kapcsolódik. Jelen tanulmány elsősorban ez utóbbira fókuszál.

A pszichológiai jóllét többtényezős modelljét Ryff (1989a) alkotta meg, döntően az optimális öregedésről, a pozitív múködésről és az optimális fejlődésről szóló elméleti összefoglaló tanulmányok alapján. Ryff, miután áttekintette a korábbi irodalmakat, úgy találta, hogy a pszichológiai egészség azokban fellelhető szempontjai egy olyan többdimenziós jóllét modellbe integrálhatók, amely a következő összetevőket tartalmazza: az (1) egyén pozitív értékelését önmaga és az élete iránt, a (2) folyamatos növekedés és a személyiség fejlődésének érzetét, azt a (3) hitet, hogy az egyén élete céltudatos és jelentésteli, hogy (4) minőségi kapcsolatban van másokkal, valamint, hogy rendelkezik az (5) élete és az ôt körülvevő világ hatékony irányítására való kapacitással, illetve az (6) önmeghatározásra való képességgel (Ryff \& Keyes, 1995).

A személyiség és jóllét összefüggésére vonatkozólag több nézet is megfogalmazásra került, amelyek McCrae és Costa (1991) szerint alapvetően két csoportba sorolhatóak (lásd még pl. Ng, 2015). Az elméletek első csoportja direkt kapcsolatot feltételez a személyiség és a jóllét között, a második csoportba tartozó elképzelések pedig az indirekt kapcsolat létezése mellett érvelnek. A direkt hatás mellett érvelő elméletek egyrészt egy személyiség által meghatározott alapszintet tételeznek fel a jóllét vonatkozásában (Headey \& Wearing, 1992), másrészt az érzelmi reaktivitást (Larsen \& Ketelaar, 1989, 1991; Rusting \& Larsen, 1997; Tellegen, 1985) és az érzelmi információ kognitív feldolgozását hangsúlyozzák (Rusting, 1998). Az érzelmi reaktivitást hangsúlyozó magyarázatok Gray $(1970,1991)$ személyiségelméletéből indulnak ki és azt feltételezik, hogy az extravertált személyek reaktívabbak a kellemes érzelmi ingerekre, mint az introvertáltak, a neuroticizmus magas szintjével jellemezhetô személyek pedig reaktívabbak a kellemetlen érzelmi ingerekre, mint az érzelmileg stabilabb személyek. Az indirekt megközelítések azt hangsúlyozzák, hogy a különböző események és életkörülmények különböző módon hatnak a jóllétre attól függően, hogy az egyénnek milyen a személyisége (McCrae \& Costa, 1991). 
Jelen kutatás különböző személyiségdimenziók (a személyiség ötfaktoros modelljét, az ún. big five-ot alkotó faktorok, valamint a diszpozicionális optimizmus), szociodemográfiai faktorok és a pszichológiai jóllét összefüggéseinek elemzésére vállalkozik magyar felnőtt korúak mintáján. A személyiség big five vonásai és a jóllét közötti kapcsolatot számos korábbi kutatás vizsgálta (metaanalízisek a témában: DeNeve \& Cooper, 1998; Steel, Schmidt, \& Schultz, 2008). A kutatások többsége a jóllét mutatók közül az ún. szubjektív jóllétet (Diener, 1984) elemezte, és eddig kevesebb figyelem irányult a pszichológiai jóllét és a személyiség összefüggéseire (az idetartozó kutatások áttekintését lásd: Ryff, 2014). A korábbi kutatások nagyrészt az extraverzió pozitív, illetve a neuroticizmus negatív irányú jólléttel való összefüggését igazolták (szubjektív jóllét: Diener, 1984; Lucas \& Fujita, 2000; Wilson, 1967; pszichológiai jóllét: Abbott és mtsai, 2008). Szintén számos korábbi kutatás irányult az optimizmus testi-lelki egészségi állapottal való összefüggéseire, e korábbi kutatások döntő többsége arra fókuszált, hogy miképpen kapcsolódik az optimizmus különbözó negatív kimenetelekhez (depresszió, szorongás, testi betegségek), egyelőre kevés olyan kutatás ismert, amely a pozitív pszichológiai múködés indikátorait vette figyelembe (élettel való elégedettség, pszichológiai jóllét). Ezek a kutatások rámutattak arra, hogy a diszpozicionális optimizmus pozitív irányú összefüggést mutat a szubjektív jóllét szintjével (Alarcon, Bowling, \& Khazon, 2013; Lucas, Diener, \& Suh, 1996), illetve a pszichológiai jóllét mértékével is (Ferguson \& Goodwin, 2010; Ibironke \& Donald, 2015). Jelen tanulmány arra keresi a választ, hogy milyen mértékben alkalmas a személyiség a pszichológiai jóllét szintjének előrejelzésére (figyelembe véve a demográfiai tényezők hatását is) magyar mintán, illetve, hogy a diszpozicionális optimizmus képes-e bejósolni a pszichológiai jóllét szintjét a big five dimenziók kontrollálása után is.

\section{Módszer}

\subsection{Minta}

A kutatásban 18 évnél idősebb magyar felnőttek vettek részt, összesen 325 fő. A mintából eltávolítottuk azokat az outliereket, akiknek a jóllét-, illetve személyiségfaktor-pontszámai több mint háromszórásnyira voltak a minta átlagától a kritikus önbevallásos változók tekintetében. E szúrés során 11 fó adatát távolítottuk el, vagyis az elemzésekhez használt minta elemszáma 314. A válaszadók 36,0\%-a férfi (113 fő) és 63,7\%-a nő (200fő). ${ }^{1}$ A vizsgálat

1 Egy vizsgálati személy nem adott meg nemére vonatkozó adatot. 
résztvevői a kérdőívfelvételt végző személyek (a személyiségpszichológiai múhelymunkán dolgozó BA pszichológushallgatók) ismeretségi köréből kerültek ki, és önként jelentkeztek a kutatásban való részvételre. A mintába történő beválasztás egyedüli kritériuma a 18 éven felüli életkor volt. A legfiatalabb résztvevő 18 éves, a legidősebb 74 éves volt az adatgyújtés időpontjában. Az átlagéletkor 29,50 év (SD = 10,96). A minta 44,3\%-a (139fó) aktív dolgozó. ${ }^{2}$ 43,9\%-a (138 fó) rendelkezik felsőfokú végzettséggel, 53,8\%-nak (169 fő) középiskolai végzettsége van. Mivel a megkérdezettek nagyon alacsony aránya rendelkezik általános iskolai végzettséggel (2,2\%, 7 fő) őket kihagytuk a további, iskolázottságot érintő elemzésekből, illetve szintén elenyészően alacsony volt a szakmunkásképző végzettséggel rendelkezők aránya, ők az elemzések során a középiskolai blokk részét képezik. A megkérdezettek 23,9\%-a, vagyis 75 fó házasságban él, 138 fó (43,9\%) élettársi vagy párkapcsolatban él, 98 fő (31,2\%) pedig egyedülálló. 27 fő (8,6\%) átlag alattinak, 211 fő $(67,2 \%)$ átlagosnak és 61 fó $(19,4 \%)$ átlag felettinek értékelte anyagi helyzetét. A résztvevők többsége Budapesten él (21,7\% - 68 fő Budán; 30,9\% - 97 fó Pesten), 16,2\% faluban (51 fö), 13,7\% vidéki kisvárosban (43 fő), 12,4\% vidéki nagyvárosban él (39 fó). 19 fó (6,1\%) esetében az apa iskolai végzettsége legfeljebb általános iskola, 79 fő $(25,2 \%)$ esetében szakmunkásképző, 72 fö (22,9\%) esetében középiskola, valamint 137 fő (43,6\%) esetében főiskola vagy egyetem. Az anya iskolai végzettsége 32 fő (10,2\%) esetében legfeljebb általános iskola, 34 fó (10,8\%) esetében szakmunkásképző, 99 fő (31,5\%) esetében középiskola és 145 fő (46,2\%) esetében főiskola vagy egyetem.

\subsection{Eljárás}

A vizsgált személyek a tesztfelvétel előtt elolvastak egy írásos tájékoztatót a kutatásról, majd a részvételi szándékukat a beleegyezó nyilatkozat aláírásával jelezték. A kérdőívek kitöltése egyénileg, papír alapon történt. A kvantitatív adatok mellett, nyílt végú kérdéseket is feltettünk a résztvevőknek a

\footnotetext{
2 A továbbiakban jellemzésre kerülő valamennyi szociodemográfiai változó esetében voltak hiányzó adatok a mintában, ennek következtében a százalékos értékek összege nem éri el a 100-at. A hiányzó adatok aránya változónként lebontva a következő: életkor - 88 fő (28,0\%); gazdasági aktivitás - 13 fó $(4,1 \%)$; iskolázottság - 7 fó (2,2\%, a törzsszövegben említett okokból kifolyólag); családi állapot - 3 fó (1\%); anyagi helyzet - 15 fó (4,8\%); lakóhely - 16 fó (5,1\%); apa végzettsége - 7 fó (2,2\%); anya végzettsége - 4 fó (1,3\%). A további vizsgált változók esetében: jóllét-pontszám - 5 fó $(1,6 \%)$; optimizmus - 1 fó $(0,3 \%)$; extraverzió - 5 fő $(1,6 \%)$; barátságosság - 4 fó $(1,3 \%)$; lelkiismeretesség - 5 fó (1,6\%); neuroticizmus - 6 fő $(1,9 \%)$; nyitottság - 4 fő (1,3\%).
} 
boldogsággal kapcsolatban. A kvalitatív adatok elemzése nem célkitúzése jelen tanulmánynak. A kutatást az ELTE PPK Kutatásetikai Bizottsága engedélyezte (engedély száma: 2012/58).

A mintába választás kényelmi mintavétellel, hólabda módszer alkalmazásával, e-mailes megkeresés útján történt. A kutatásban való részvétel önkéntes és anonim volt. A vizsgálat első lépéseként különböző szociodemográfiai adatokat rögzítettünk: nem, életkor, a vizsgált személy gazdasági aktivitása, iskolai végzettsége, családi státusza, anyagi helyzete, jelenlegi lakóhelye, az apa iskolai végzettsége és az anya iskolai végzettsége. A vizsgálat második lépésében a későbbiekben részletezett kérdőíveket töltötték ki a vizsgálati személyek. Végezetül, különböző, boldogsággal összefüggó nyitott kérdésekre válaszoltak írásos formában a résztvevők.

\subsection{Méróeszközök}

Big Five Kérdőív. A személyiség mérésére a Big Five Kérdőívet (Big Five Questionnaire, BFQ; Carpara, Barbaranelli, Borgogni, \& Perugini, 1993) alkalmaztuk, amelynek magyar nyelvú adaptációját Rózsa, Kő és Oláh (2006) végezték el. A BFQ a személyiség öt fó dimenziójának (extraverzió, barátságosság, lelkiismeretesség, neuroticizmus, nyitottság) megfeleltethető skálákat tartalmaz. A vizsgálati személyeknek egy ötfokozatú Likert-típusú skála segítségével kell megjelölni, hogy mennyire illik rájuk a 132 állítás (végpontok: 1-5). A skálákon elért magasabb pontszám az extraverzió, barátságosság, lelkiismeretesség, érzelmi stabilitás és nyitottság magasabb szintjeit jelzi. Jelen kutatásban a BFQ alskáláinak megbízhatósága megfelelőnek bizonyult, a belső konzisztenciát jelző Cronbach-a értéke 0,73 és 0,88 között volt.

Pszichológiai Jóllét Kérdőív. A pszichológiai jóllét mérése a magyar nyelven is elérhető Pszichológia Jóllét Kérdőív (Scales of Psychological Well-Being, PWB, Ryff, 1989a; Oláh, 2012) alkalmazásával történt. Az első megjelenés óta a méróeszköznek több különböző verziója is kidolgozásra került, jelen kutatásban a 18 tételes változatot alkalmaztuk. A tesztkitöltő személyek hatfokozatú Likert-típusú skálák alapján pontozzák egyetértésüket az állításokkal (végpontok: 1-6). Kutatásunkban a kérdőív 6 skálájának összesített pontértékét, a pozitív pszichológiai múködés (PWB teljes pontszám) mutatót vettük figyelembe (a magasabb összpontszám magasabb pszichológiai jóllétszintet jelez). Ennek oka, hogy számos korábbi tanulmány (pl. Abbott, Ploubidis, Huppert, Kuh, \& Groudace, 2010; Kafka \& Kozma, 2002; Springer, Hauser, \& Freese, 2006) kérdőjelezte meg a skála hatfaktoros struktúráját, illetve az alskálák belső megbízhatóságát, amely jelen kutatás során is az 
elvártnál alacsonyabbnak bizonyult (Cronbach-a: 0,46-0,69). A teszt validitása és összesített pszichológiai jóllét skála megbízhatósága megfelel az elvárásoknak (Ryff \& Keyes, 1995; a magyar nyelvú változat esetében: Oláh, 2012). Jelen kutatásban a PWB összesített skála megbízhatósága megfelelő volt $(a=0,78)$.

Életszemlélet Teszt. A diszpozicionális optimizmus mérése a 12 tételból álló Életszemlélet Teszt (Life Orientation Test, LOT; Scheier \& Carver, 1985) alkalmazásával történt. A tesztkitöltés során a résztvevők egy 1-től 4-ig terjedő Likert-típusú skálán pontozzák az állításokat. A skálán elért magasabb pontszám a diszpozicionális optimizmus magasabb szintjét jelzi. A skála megbízhatósága és érvényessége megfelel az elvárásoknak (Scheier \& Carver, 1985; magyar nyelvú változat: Oláh, 2005). Jelen kutatásban a kérdőív belső konzisztenciája szintén kielégítő volt $(\alpha=0,76)$.

\subsection{Statisztikai elemzések}

A skálák belső megbízhatóságának becslésére Cronbach-a-mutatót számítottunk. A paraméteres statisztikai eljárások normális eloszlás előfeltételének ellenőrzése céljából a folytonos változók eloszlását három módon vizsgáltuk: a Kolmogorov-Smirnov próba elvégzésével, a QQ-grafikonok vizsgálatával, valamint a változók eloszlásának egyszerú szemrevételezésével (hisztogramok segítségével).

Egyszempontos varianciaanalízissel vizsgáltuk, hogy a különböző szociodemográfiai változók mentén képzett csoportok között mutatkozik-e különbség a pszichológiai jóllét tekintetében. A pszichológiai jóllét és a személyiség, illetve életkor összefüggéseit korrelációs elemzéssel teszteltük. A normalitás sérülése esetén a Spearman-féle rangkorrelációs elemzést alkalmaztunk. A pszichológiai jóllét és a személyiség összefüggését a szociodemográfiai változók kontrollálása mellett bináris logisztikus regresszió elemzés segítségével teszteltük. Azért ezt a próbát választottuk, mert a szociodemográfiai változók kategoriálisak, tipikusan kettőnél több értékúek, így lineáris regressziós elemzésekbe csupán bináris dummy-változók képzése után léptethetők be. Jelen esetben a dummy-változók használata indokolatlanul megemelte volna a prediktorok számát, valamint az eredmények értelmezhetőségét is megnehezítette volna. A bináris logisztikus regresszió elemzés esetében mind a kategoriális, mind pedig a folytonos prediktorokra vonatkozó eredmények könnyen értelmezhetóek, így ez az elemzés - a pszichológiai jóllét változó dichotomizálásából fakadó információveszteséggel együtt is - megfelelő választásnak túnt. Az elemzéseket az SPSS Statistics 20 statisztikai programcsomagokkal végeztük. 


\section{Eredmények}

\subsection{Szociodemográfiai változók és jóllét}

A független mintás t-próbák eredményei szerint nem találtunk szignifikáns különbséget a férfiak és a nók között, a középfokú, illetve felsőfokú iskolai végzettségúek csoportja között; valamint az aktív dolgozó és nem aktív személyek között. Továbbá nem mutatkozott szignifikáns korreláció az életkor és a pszichológiai jóllét között sem $(\rho=-0,001, p=0,990)$. A családi állapot alapján kialakított csoportok sem különböztek egymástól szignifikánsan a jóllét mutató vonatkozásában. A varianciaanalízisek az alábbi változók esetén utaltak szignifikáns különbségre a csoportok között: az anyagi helyzet, a jelenlegi lakóhely, az apa iskolai végzettsége; és az anya iskolai végzettsége. A leíró adatokat az 1. táblázat foglalja össze e változók esetében, a továbbiakban pedig a megfelelő post-hoc elemzések (mindegyik esetben a Tukeyteszt) eredményeit közöljük. Az anyagi helyzetüket átlag felettinek ítéló személyek szignifikánsan (mindkét $\mathrm{p}<0,01$ ) magasabb pontszámot értek el a pszichológiai jóllét tekintetében, mint az anyagi helyzetüket átlag alattinak vagy átlagosnak tekintő személyek. Lakóhely szempontjából a Pesten élók magasabb szintú ( $p=0,001)$ pszichológiai jóllétről számoltak be, mint a falun élő́k. Az apa iskolai végzettsége alapján azok a személyek számoltak be a legmagasabb jóllétről, akiknél az apa felsőfokú végzettségú volt, hozzájuk képest szignifikánsan (mindkét $\mathrm{p}<0,05$ ) alacsonyabb jóllétról számoltak be azok, akiknél az apa iskolai végzettsége legfeljebb általános iskola, vagy az apa szakmunkásképző iskolába járt. Az anya iskolai végzettsége alapján a legalacsonyabb szintú pszichológiai jóllétet azok mutatták, akiknél az anya legfeljebb általános iskolát végzett, e csoport jóllét-pontszáma szignifikánsan (mindkét $\mathrm{p}<0,05)$ különbözött a középiskolai és felsőfokú végzettségú csoportokétól, és tendenciózusan eltért a szakmunkás végzettségú csoportétól $(p=0,05)$.

1. táblázat. Szociodemográfiai változók és pszichológiai jóllét

\begin{tabular}{|c|c|c|c|c|}
\hline Változók & $\mathrm{n}$ & Átlag & Szórás & F-érték \\
\hline \multicolumn{5}{|l|}{$\mathrm{Nem}$} \\
\hline Férfi & 111 & 4,55 & 0,58 & \multirow[t]{2}{*}{$F(1 ; 306)=3,91^{+}$} \\
\hline Nő & 197 & 4,68 & 0,52 & \\
\hline \multicolumn{5}{|l|}{ Gazdasági aktivitás } \\
\hline Aktív & 136 & 4,66 & 0,54 & \multirow[t]{2}{*}{$F(1 ; 294)=0,63$} \\
\hline Inaktív & 160 & 4,61 & 0,55 & \\
\hline
\end{tabular}




\begin{tabular}{|c|c|c|c|c|}
\hline Változók & $\mathrm{n}$ & Átlag & Szórás & F-érték \\
\hline \multicolumn{5}{|l|}{ Végzettség } \\
\hline Középiskola & 166 & 4,61 & 0,53 & \multirow[t]{2}{*}{$\mathrm{F}(1 ; 300)=1,50$} \\
\hline Egyetem, fóiskola & 136 & 4,68 & 0,55 & \\
\hline \multicolumn{5}{|l|}{ Családi állapot } \\
\hline Házasság & 71 & 4,52 & 0,53 & \multirow[t]{3}{*}{$\mathrm{F}(2 ; 303)=2,39^{+}$} \\
\hline Párkapcsolat & 137 & 4,69 & 0,53 & \\
\hline Egyedülálló & 98 & 4,61 & 0,56 & \\
\hline \multicolumn{5}{|l|}{ Anyagi helyzet } \\
\hline Átlag alatti & 25 & 4,34 & 0,50 & \multirow[t]{3}{*}{$\mathrm{F}(2 ; 293)=10,53^{* * *}$} \\
\hline Átlagos & 210 & 4,59 & 0,54 & \\
\hline Átlag feletti & 61 & 4,87 & 0,49 & \\
\hline \multicolumn{5}{|l|}{ Jelenlegi lakóhely } \\
\hline Buda & 68 & 4,54 & 0,61 & \multirow[t]{5}{*}{$\mathrm{F}(4 ; 288)=4,72^{* *}$} \\
\hline Pest & 96 & 4,77 & 0,49 & \\
\hline Vidéki nagyváros & 39 & 4,69 & 0,52 & \\
\hline Vidéki kisváros & 43 & 4,62 & 0,58 & \\
\hline Falu & 47 & 4,38 & 0,49 & \\
\hline \multicolumn{5}{|l|}{ Apa végzettsége } \\
\hline Legfeljebb általános iskola & 18 & 4,39 & 0,59 & \multirow[t]{4}{*}{$\mathrm{F}(3 ; 298)=4,92^{* *}$} \\
\hline Szakmunkásképző & 77 & 4,50 & 0,52 & \\
\hline Középiskola & 71 & 4,64 & 0,49 & \\
\hline Egyetem, főiskola & 136 & 4,74 & 0,54 & \\
\hline \multicolumn{5}{|l|}{ Anya végzettsége } \\
\hline Legfeljebb általános iskola & 29 & 4,21 & 0,51 & \multirow[t]{4}{*}{$\mathrm{F}(3 ; 301)=10,58^{* * *}$} \\
\hline Szakmunkásképző & 34 & 4,55 & 0,43 & \\
\hline Középiskola & 99 & 4,58 & 0,55 & \\
\hline Egyetem, főiskola & 143 & 4,78 & 0,52 & \\
\hline
\end{tabular}

Megjegyzés: ${ }^{+} \mathrm{p}<0,1,{ }^{*} \mathrm{p}<0,05,{ }^{* *} \mathrm{p}<0,01,{ }^{* * *} \mathrm{p}<0,001$. 


\subsection{A jóllét és a személyiség összefüggései}

Elsőként korrelációszámításokat végeztünk a vizsgált személyiségvonások (a BFQ dimenziói és a LOT pontszáma), valamint a pszichológiai jóllét (PWB teljes pontszám) mutatók között (lásd 2. táblázat). A személyiségváltozók közül a diszpozicionális optimizmus (LOT) a jóllétszinttel erős mértékú pozitív irányú együttjárást mutatott. A big five dimenziók pedig legfeljebb közepes mértékú összefüggést jeleztek a pszichológiai jólléttel, a neuroticizmus kivételével pozitív irányban.

2. táblázat. Megbízhatósági mutatók, leíró statisztikák és Pearson-féle korrelációs együtthatók a pszichológiai jóllét és a vizsgált személyiségváltozók között

\begin{tabular}{|c|c|c|c|c|c|c|c|c|c|}
\hline Változók & $\begin{array}{l}\text { Cron- } \\
\text { bach-a } \\
\text { (tétel- } \\
\text { szám) }\end{array}$ & $\mathrm{n}$ & $\begin{array}{l}\text { Átlag } \\
\text { (szórás) }\end{array}$ & LOT & E & B & L & $\mathrm{N}$ & $\mathrm{Ny}$ \\
\hline PWB & $\begin{array}{l}0,78 \\
(18)\end{array}$ & 309 & $\begin{array}{c}4,63 \\
(0,54)\end{array}$ & $\begin{array}{c}0,61^{* *} \\
(308)\end{array}$ & $\begin{array}{c}0,42^{* *} \\
(305)\end{array}$ & $\begin{array}{c}0,27^{* *} \\
(307)\end{array}$ & $\begin{array}{c}0,28^{* *} \\
(306)\end{array}$ & $\begin{array}{c}-0,33^{* *} \\
(304)\end{array}$ & $\begin{array}{c}0,45^{* *} \\
(307)\end{array}$ \\
\hline LOT & $\begin{array}{l}0,76 \\
(12)\end{array}$ & 313 & $\begin{array}{c}3,17 \\
(0,44)\end{array}$ & & $\begin{array}{c}0,43^{\star *} \\
(308)\end{array}$ & $\begin{array}{c}0,30 * * \\
(309)\end{array}$ & $\begin{array}{l}0,13^{*} \\
(308)\end{array}$ & $\begin{array}{c}-0,41^{* *} \\
(307)\end{array}$ & $\begin{array}{c}0,40^{* *} \\
(309)\end{array}$ \\
\hline $\mathbf{E}$ & $\begin{array}{l}0,82 \\
(24)\end{array}$ & 309 & $\begin{array}{c}3,36 \\
(0,51)\end{array}$ & & & $\begin{array}{l}-0,01 \\
(307)\end{array}$ & $\begin{array}{c}0,22^{* *} \\
(305)\end{array}$ & $\begin{array}{c}0,10 \\
(306)\end{array}$ & $\begin{array}{c}0,50^{* *} \\
(306)\end{array}$ \\
\hline B & $\begin{array}{l}0,78 \\
(24)\end{array}$ & 310 & $\begin{array}{c}3,45 \\
(0,44)\end{array}$ & & & & $\begin{array}{c}0,15^{* *} \\
(307)\end{array}$ & $\begin{array}{c}-0,26^{* *} \\
(305)\end{array}$ & $\begin{array}{c}0,23^{* *} \\
(307)\end{array}$ \\
\hline $\mathbf{L}$ & $\begin{array}{l}0,77 \\
(24)\end{array}$ & 309 & $\begin{array}{c}3,49 \\
(0,44)\end{array}$ & & & & & $\begin{array}{c}0,00 \\
(304)\end{array}$ & $\begin{array}{c}0,24^{\star *} \\
(306)\end{array}$ \\
\hline $\mathbf{N}$ & $\begin{array}{l}0,88 \\
(24)\end{array}$ & 308 & $\begin{array}{c}3,03 \\
(0,60)\end{array}$ & & & & & & $\begin{array}{l}-0,09 \\
(305)\end{array}$ \\
\hline Ny & $\begin{array}{l}0,72 \\
(24)\end{array}$ & 310 & $\begin{array}{c}3,47 \\
(0,42)\end{array}$ & & & & & & \\
\hline
\end{tabular}

Megjegyzés: PWB = Pszichológiai jóllét; LOT = Diszpozicionális optimizmus;

$\mathrm{E}=$ Extraverzió; $\mathrm{B}=$ Barátságosság; $\mathrm{L}=$ Lelkiismeretesség; $\mathrm{N}=$ Neuroticizmus;

Ny $=$ Nyitottság. ${ }^{*} \mathrm{p}<0,05,{ }^{* *} \mathrm{p}<0,01$.

A következő lépésben bináris logisztikus regresszióelemzés alkalmazásával azt vizsgáltuk, hogy megmarad-e a személyiség és a pszichológiai jóllét közötti összefüggés a demográfiai változók (anyagi helyzet, lakóhely, apa is- 
kolai végzettsége, anya iskolai végzettsége) kontrollálása után is. A pszichológiai jóllét-összpontszám mediánja mentén két csoportra - alacsony jóllétú (pontszám: $<4,72$; átlag $=4,19 ; \mathrm{SD}=0,37, \mathrm{n}=154$ ) és magas jóllétú (pontszám: $\geq 4,72$; átlag $=5,07 ; \mathrm{SD}=0,26 ; \mathrm{n}=155$ ) csoportok - osztottuk a mintát. ${ }^{3}$ Ez a kétértékú jóllét-változó képezte a bináris logisztikus regresszió elemzés függő változóját. Ezek után három prediktív modellt építettünk: az elsőbe csupán a szociodemográfiai változókat léptettük be (a referenciakategóriák a következők voltak: az anyagi helyzet és a szülők végzettsége esetében a legalacsonyabb kategória, vagyis - rendre - az átlag alatti anyagi helyzet, és a legfeljebb általános iskolai végzettség; míg a jelenlegi lakóhely esetében a falun élő csoport volt a viszonyítási pont). A második modellbe a fenti változók mellett beléptettük az ötfaktoros személyiségmodell dimenzióit is, a harmadikba pedig a második modell változóin túl az optimizmust is. A tömörség és áttekinthetőség érdekében a 3-4. táblázatban csupán a 2. és 3. modellre vonatkozó adatokat tüntettük fel. A szociodemográfiai értékekre vonatkozó adatokat (1. modell) a szerzők kérésre biztosítják. Az elemzések elemszáma 262 fó volt - ez azokat a vizsgálati személyeket jelenti, akik mind a négyfajta adattal rendelkeztek (szociodemográfiai jellemzők, személyiségfaktorok, optimizmus, pszichológiai jóllét).

Az első modell esetében a megmagyarázott variancia (Nagelkerke-féle $\left.R^{2}\right) 17,5 \%$ volt $\left(\chi^{2}(12)=36,80 ; p<0,001\right)$. A változók közül azonban csupán az anya iskolai végzettségének volt szignifikáns bejósló ereje - a magas jóllétú csoportba kerülés esélye 4,52-szer (95\% CI: 1,49-13,72) nagyobb azoknál, akiknek az édesanyja egyetemet végzett, azokhoz képest, akiké legfeljebb általános iskolát. E modell az esetek 64,1\%-át klasszifikálta helyesen.

A második modell eredményei szerint (1. 3. táblázat) a big five vonások mind szignifikáns hatást gyakoroltak a pszichológiai jóllét szintjére - ez valamennyi dimenzió esetében pozitív, a neuroticizmust leszámítva, ugyanakkor az anyai iskolai végzettség elvesztette szignifikáns prediktív erejét a pszichológiai jóllétre nézve. A modell által megmagyarázott variancia 59,9\%-ra emelkedett $\left(\chi^{2}(17)=156,35 ; p<0,001 ;\right.$ az elsó modellhez képest a $\chi^{2}$-változás szignifikáns: $\left.\Delta \chi^{2}(5)=119,55 ; p<0,001\right)$. Ez a modell az esetek $81,7 \%$-át klasszifikálta helyesen.

3 A két csoport szignifikánsan különbözött jóllét tekintetében ( $\mathrm{t}(275)=-24,64, \mathrm{p}<0,001)$. 
3. táblázat. A pszichológiai jólllét prediktorai a bináris logisztikus regresszió eredményei

\begin{tabular}{|c|c|c|c|c|}
\hline \multirow[t]{2}{*}{ Modell } & \multirow[t]{2}{*}{ Változó } & \multirow[t]{2}{*}{ OR } & \multicolumn{2}{|c|}{$95 \%$ CI (OR) } \\
\hline & & & Alsó határ & Felső határ \\
\hline \multirow[t]{25}{*}{ 2. modell } & \multicolumn{2}{|l|}{ Anyagi helyzet } & & \\
\hline & Átlag alatti anyagi helyzet & (REF) & & \\
\hline & Átlagos anyagi helyzet & 0,90 & 0,25 & 3,28 \\
\hline & Átlag feletti anyagi helyzet & 1,57 & 0,32 & 7,67 \\
\hline & Lakóhely & & & \\
\hline & Buda & 0,42 & 0,11 & 1,56 \\
\hline & Pest & 1,46 & 0,44 & 4,81 \\
\hline & Vidéki nagyváros & 1,54 & 0,36 & 6,49 \\
\hline & Vidéki kisváros & 1,39 & 0,38 & 5,08 \\
\hline & Falu & (REF) & & \\
\hline & \multicolumn{2}{|l|}{ Apa végzettsége } & & \\
\hline & Általános iskola & (REF) & & \\
\hline & Szakmunkásképző & 0,68 & 0,11 & 4,11 \\
\hline & Középiskola & 2,21 & 0,33 & 14,86 \\
\hline & Egyetem, főiskola & 2,32 & 0,34 & 15,79 \\
\hline & \multicolumn{2}{|l|}{ Anya végzettsége } & & \\
\hline & Általános iskola & (REF) & & \\
\hline & Szakmunkásképző & 0,46 & 0,09 & 2,39 \\
\hline & Középiskola & 0,91 & 0,21 & 3,98 \\
\hline & Egyetem, fóiskola & 1,32 & 0,30 & 5,91 \\
\hline & Extraverzió & $13,32^{* *}$ & 5,19 & 34,14 \\
\hline & Barátságosság & $3,03^{*}$ & 1,23 & 7,46 \\
\hline & Lelkiismeretesség & $2,59 *$ & 1,08 & 6,21 \\
\hline & Neuroticizmus & $0,18^{* *}$ & 0,09 & 0,36 \\
\hline & Nyitottság & $5,37^{* *}$ & 1,78 & 16,25 \\
\hline
\end{tabular}

Megjegyzés: OR = odds ratio, esélyhányados; 95\% CI = 95\%-os konfidencia intervallum; $(\mathrm{REF})=$ referenciakategória. ${ }^{*} \mathrm{p}<0,05,{ }^{* *} \mathrm{p}<0,01$. 
Az optimizmus bevezetése mindegyik személyiségvonással kapott öszszefüggés erősségét csökkentette (a barátságosság esetében például a megelőző modellben szignifikáns hozzájárulás megszúnt szignifikánsnak lenni). Mivel a 3. modell által megmagyarázott variancia szignifikánsan magasabb a 2. modell által megmagyarázottnál, az eredmények azt sugallják, hogy az optimizmus önálló, a big five dimenzióktól független magyarázóeróvel bír a pszichológiai jóllét szintjének alakulása tekintetében. A harmadik modell esetében a megmagyarázott variancia $61,7 \%\left(\chi^{2}(18)=162,75 ; p<0,001\right)$, és az előző modellhez képest a $\chi^{2}$-változás szignifikáns volt $\left(\Delta \chi^{2}(1)=6,39 ; p=\right.$ $0,011)$. Ez a modell az esetek $80,5 \%$-át klasszifikálta helyesen. Az eredményeket a 4. táblázatban részletezzük.

A Hosmer-Lemeshow-féle illeszkedési próba egyik esetben sem utalt nem megfeleló illeszkedésre (minden $\mathrm{p}>0,15$ ).

\section{Megbeszélés}

Kutatásunkban a pszichológiai jóllét szintjének szociodemográfiai változókkal és személyiség dimenziókkal való összefüggéseire fókuszáltunk, egy, a pozitív pszichológiai múködést jelző összesített mutató, a pszichológiai jóllét alkalmazásával. A vizsgált szociodemográfiai tényezók közül mintánkban az életkor nem mutatott lineáris összefüggést a jóllét szintjének alakulásával. Az életkor egy olyan változó, amely korábbi kutatások szerint eltérő összefüggést mutat a szubjektív jóllét specifikus komponenseivel: az életkor emelkedésével kismértékú csökkenés figyelhető meg a pozitív affektusok területén, és nincs változás a negatív affektusok vonatkozásában (Andrews \& McKennel, 1980). Gutiérrez és munkatársai (Guitérrez, Jiménez, Hernández, \& Puente, 2005) szerint az életkor és a jóllét közötti kapcsolatot feltehetóen egyéb változók befolyásolják, úgymint az anyagi helyzet, a foglalkozás, az iskolai végzettség, a családi helyzet vagy a nemzetiség, és valószerüsíthető, hogy maga a személyiség is egy olyan változó, amely befolyásolhatja az életkor és a jóllét között tapasztalt összefüggéseket. A pszichológiai jóllét és az életkor összefüggéseit vizsgáló kutatások (pl. Ryff, 1989b; Ryff \& Keyes, 2005) azt mutatják, hogy néhány pszichológiai jóllét skála esetében (életcélok, személyes növekedés) az idősebbek alacsonyabb értékeket érnek el, mint a fiatalok vagy a középkorúak. Úgy túnik továbbá, hogy máshogy függ össze az életkor és a pszichológiai jóllét a különböző kultúrákban (Karasawa és mtsai, 2011), illetve, hogy a jóllétet különösen az élet későbbi szakaszában befolyásolják a szocioökonómiai változók is (Clarke, Marshall, Ryff, \& Rosenthal, 2000). 
4. táblázat. A pszichológiai jóllét prediktorai a bináris logisztikus regresszió eredményei

\begin{tabular}{|c|c|c|c|c|}
\hline \multirow[t]{2}{*}{ Modell } & \multirow[t]{2}{*}{ Változó } & \multirow[t]{2}{*}{ OR } & \multicolumn{2}{|c|}{$95 \% \mathrm{CI}(\mathrm{OR})$} \\
\hline & & & Alsó határ & Felső határ \\
\hline \multirow[t]{26}{*}{ 3. modell } & \multicolumn{2}{|l|}{ Anyagi helyzet } & & \\
\hline & Átlag alatti anyagi helyzet & (REF) & & \\
\hline & Átlagos anyagi helyzet & 0,75 & 0,19 & 2,92 \\
\hline & Átlag feletti anyagi helyzet & 1,18 & 0,22 & 6,35 \\
\hline & Lakóhely & & & \\
\hline & Buda & 0,40 & 0,10 & 1,55 \\
\hline & Pest & 1,35 & 0,39 & 4,62 \\
\hline & Vidéki nagyváros & 1,47 & 0,34 & 6,42 \\
\hline & Vidéki kisváros & 1,21 & 0,32 & 4,56 \\
\hline & Falu & (REF) & & \\
\hline & \multicolumn{2}{|l|}{ Apa végzettsége } & & \\
\hline & Általános iskola & (REF) & & \\
\hline & Szakmunkásképző & 0,65 & 0,11 & 4,01 \\
\hline & Középiskola & 1,78 & 0,25 & 12,47 \\
\hline & Egyetem, föiskola & 2,19 & 0,31 & 15,40 \\
\hline & \multicolumn{2}{|l|}{ Anya végzettsége } & & \\
\hline & Általános iskola & (REF) & & \\
\hline & Szakmunkásképző & 0,43 & 0,08 & 2,30 \\
\hline & Középiskola & 0,78 & 0,17 & 3,57 \\
\hline & Egyetem, főiskola & 1,05 & 0,23 & 4,81 \\
\hline & Extraverzió & $8,44^{* *}$ & 3,15 & 22,59 \\
\hline & Barátságosság & 2,44 & 0,97 & 6,15 \\
\hline & Lelkiismeretesség & $2,81^{*}$ & 1,11 & 7,12 \\
\hline & Neuroticizmus & $0,25^{* *}$ & 0,12 & 0,51 \\
\hline & Nyitottság & $5,26^{* *}$ & 1,70 & 16,29 \\
\hline & Optimizmus & $4,32 *$ & 1,35 & 13,84 \\
\hline
\end{tabular}

Megjegyzés: OR = odds ratio, esélyhányados; 95\% CI = 95\%-os konfidencia intervallum; $(\mathrm{REF})=$ referenciakategória. ${ }^{*} \mathrm{p}<0,05,{ }^{* *} \mathrm{p}<0,01$. 
Nem találtunk különbséget a férfiak és nők általános pszichológiai jóllétszintje között - habár természetesen a nullhatások értelmezése nem könnyú feladat, ez az eredmény egybecseng a korábbi kutatások eredményeivel, amelyek azt jelzik, hogy a szubjektív jóllét területén nem jelentkeznek nemi különbségek, vagy ha igen, akkor ezek nagyon kismértékúek ${ }^{4}$ (Inglehart, 1990; Michalos, 1991). A pszichológiai jóllét vonatkozásában Ryff (1989b) azt találta, hogy a nők a férfiaknál magasabb értékeket érnek el a másokkal való pozitív kapcsolatokban és a személyes növekedésben. Jelen kutatásban azonban nem vizsgáltuk a pszichológiai jóllét egyes komponenseit elkülönítve.

Mintánkban a vizsgált személyek iskolai végzettsége, gazdasági aktivitása és családi állapota nem függött össze szignifikánsan a jóllét szintjével. Korábbi kutatások az eredményeinkkel egybecsengően azt mutatták, hogy az intelligencia és az iskolai végzettség nem jelzi előre a szubjektív jóllétet (Diener, 1984; Myers, 1992). A házasságban élés viszont korábbi szakirodalmi adatok alapján megbízható bejóslónak tûnt a szubjektív jóllét alakulása szempontjából (Diener, 1984; Myers, 1992), illetve az eredmények tipikusan azt jelezték, hogy általában a partner jelenléte egy olyan változó, ami összefüggést mutat a magasabb szintú szubjektív jólléttel. Gutiérrez és munkatársai (2005) azonban felhívták a figyelmet arra, hogy ha úgy vizsgáljuk a párkapcsolati státusz és a szubjektív jóllét közötti kapcsolatot, hogy közben a személyiség (extraverzió és neuroticizmus) hatását kontroll alatt tartjuk, akkor ez az összefüggés eltúnik. A pszichológiai jóllét vonatkozásában Bierman, Fazio és Milkie (2006) szerint a házasok, az elváltakhoz és azokhoz képest, akik soha nem házasodtak meg magasabb szintú pszichológiai jóllétet mutatnak (konkrétan az életcélok tekintetében érnek el magasabb értéket), amely különbség részben magyarázható a szocioökonómiai erőforrásokkal. Ugyanakkor, más kutatások eredményei arra mutatnak rá, hogy az egyedülálló nők az autonómia és a személyes növekedés faktorokon magasabb értékeket érnek el, mint a házasok (Marks \& Lambert, 1998). A pszichológiai jóllét területén tehát úgy túnik, lényeges eltérések vannak a skálák vonatkozásában, amelyet jelen kutatás nem vett figyelembe, mivel csak a skálák összesítésével képzett mutatóval számoltunk pszichometriai megfontolásokból. Emellett természetesen e változó esetében is elképzelhetô, hogy a jelen kutatás csupán nem rendelkezett elég statisztikai erővel (power) ahhoz, hogy kimutassa a családi állapot mentén jelentkező különbségeket, vagyis a különbség hiánya inkább statisztikai okokra vezethetó vissza, semmint elméletiekre.

\footnotetext{
4 A nők tendenciózus fölényére a mi adataink is utaltak, és elképzelhető, hogy egy nagyobb mintán, nagyobb statisztikai erő mellett ez a különbség szignifikáns lett volna.
} 
Jelen kutatásban az anyagi helyzet, a lakóhely és a szülók iskolai végzettsége mutatkozott lényegesnek a pszichológiai jóllét szintjének alakulása szempontjából. A legmagasabb szintú jóllét mutatóról azok a résztvevők számoltak be, akik az átlagosnál jobb anyagi körülmények között, a fővárosban (és azon belül Pesten) élnek, illetve akiknek a szülei felsőfokú iskolai végzettséggel rendelkeznek. Ezek tipikusan azok a változók, amelyek a nagyrészt fiatalkorúakból álló minta szocioökonómiai státuszát (SES) meghatározzák. Korábbi kutatási eredmények az anyagi helyzettel kapcsolatban arra mutattak rá, hogy ez a változó összefüggést mutat a szubjektív jólléttel a szegényebb nemzetekben, de nem mutat összefüggést a gazdagabb nemzetekben (Veenhoven, 1993). DeNeve és Cooper (1998) metaanalízise is felhívta a figyelmet arra, hogy a szubjektív jóllét legfontosabb korrelátuma az egészség, és a személyiség mellett a SES, ugyanakkor a legtöbb demográfiai és szociális faktor (úgymint életkor, nem, családi állapot) független a szubjektív jólléttől. Jelen kutatás eredményei a pszichológiai jóllét esetében is hasonló összefüggéseket sejtetnek. Érdemes emellett kiemelni azt is, hogy amikor az említett szociodemográfiai változókat egyidejúleg léptettük statisztikai modellünkbe, csupán az anya iskolai végzettsége bizonyult a jóllét szignifikáns prediktorának; a személyiségdimenziók figyelembevétele után pedig egyik változó hozzájárulása sem maradt jelentős. Mindez arra utal, hogy a pszichológiai jóllét szintjének alakulásában is markánsabb hatással bír egy egyén személyisége, mint a szociodemográfiai háttere.

A személyiség és jóllét közötti kapcsolatra irányuló elemzéseink azt mutatták, hogy a diszpozicionális optimizmus a pszichológiai jólléttel erős pozitív irányú együttjárást mutat, a big five vonások pedig csak legfeljebb közepes mértékben mutatnak együttjárást a jóllét szintjével. A bináris logisztikus regresszió eredményei alapján a big five személyiségvonások mind szignifikáns hatást gyakorolnak a jóllét szintjére, egymás, illetve a szociodemográfiai változók kontrollja mellett. A faktorok hatása pozitív az extraverzió, barátságosság, lelkiismeretesség és nyitottság esetében, és negatív a neuroticizmus esetén. Az eredmények azt is sugallják, hogy az optimizmus önálló, a big five dimenzióktól - valamint a szociodemográfiai jellemzóktől - független magyarázóerővel bír a pszichológiai jóllét szintjének alakulása tekintetében. Korábbi kutatások, jelen kutatás eredményeihez hasonlóan összefüggést találtak a szubjektív jóllét és az extraverzió, illetve a neuroticizmus között (Costa \& McCrae, 1980; Headey \& Wearing, 1992), valamint a lelkiismeretesség és a szubjektív jóllét között (DeNeve \& Cooper, 1998; Hayes \& Joseph, 2003). A pszichológiai jóllét területén végzett kutatások (Schmutte \& Ryff, 1997) szintén az extraverziót, a neuroticizmust és lelkiismeretességet hozták összefüggésbe a jóllét magasabb szintjeivel. A nyitottsággal kapcsolatban ellentmondásosak a korábbi eredmények (DeNeve \& Cooper, 1998; Gutiérrez és mtsai, 2005), feltehetőleg éppen azért, mert a 
nyitottság a szociodemográfiai változókkal általában jelentős együttjárást mutat, valamint azért, mert e dimenzió tartalma vitatott, és mérőeszköztől függően eltérő lehet. A barátságosság esetén pedig a mintánkban kimutatott pozitív összefüggés eltúnt az optimizmus modellbe léptetése után vagyis elképzelhető, hogy a barátságosság és a jóllét kapcsolatát az optimizmus mediálja.

Összefoglalva, jelen kutatás egy újabb bizonyíték azon vizsgálatok sorában, amelyek azt demonstrálják, hogy a személyiség lényeges szerepet játszik a jóllét alakulásában. Konklúzióként megfogalmazhatjuk, hogy az eredményeink amellett, hogy megerósítik a korábbi eredményeket, amelyek szerint a pszichológiai jóllét szintjének alakulása szempontjából a big five dimenziók befolyásoló szerepe meghatározó lehet, felhívják a figyelmet arra is, hogy az optimizmusnak is jelentős, az öt faktortól független jóllétszintet befolyásoló szerepe lehet. A szubjektív jóllét vonatkozásában hasonló eredményt kapott Lauriola és Iani (2015), akik igazolták, hogy a személyiségvonások - extraverzió, neuroticizmus - hatását a boldogságra a pozitivitás (önértékelés, optimizmus, élettel való elégedettség) mediálja. Meg kell azonban jegyeznünk, hogy jelen tanulmányban csak egy módszerrel mértük az optimizmust, így eredményeink csak a diszpozicionális optimizmusnak (Carver és Scheier, 1981, 1990) a pszichológiai jóllétre gyakorolt hatásához kapcsolódnak. Legújabban Kleiman és munkatársai (2015) kutatása igazolta, hogy az optimizmus különböző elméleti meghatározásai és mérési eljárásai eltérő kapcsolatot mutatnak a testi-lelki jólléttel. A jövőbeli kutatásokban ezért szükséges lesz más optimizmust méró módszerek alkalmazásával is megvizsgálni az optimizmus és a jóllét kapcsolatát. Bár úgy túnik, a személyiségnek lényeges szerepe lehet a jóllét alakulása szempontjából, a jövőbeli kutatásoknak pontosabban kell tisztázni, hogy melyek azok a folyamatok, amelyek ezekért az összefüggésekért felelősek. Nemcsak azt fontos megvizsgálni, hogy mely személyiségváltozók alapvető fontosságúak a jóllét alakulása szempontjából, hanem azt is, hogy egy-egy személyiségvonás közvetlen hatást gyakorol-e a jóllétre vagy más változók közvetítik hatását. További kihívás tisztázni, hogy a személyiség és jóllét között tapasztalt összefüggések mennyiben általánosíthatók a különböző kultúrákra.

Végezetül szót kell ejtenünk kutatásunk limitációiról is. Elsőként kell említeni a mintavétel módját, vagyis a kényelmi mintavételt, amely nem teszi lehetővé az eredmények jelen mintán túl történő általánosítását. A keresztmetszeti kutatási elrendezés pedig nem teszi lehetővé, hogy az okság irányával kapcsolatban következtetéseket vonjunk le. Soto (2015) egy friss longitudinális kutatás keretében azt találta, hogy azok a személyek, akik az első mérés alkalmával extravertáltak, barátságosak és érzelmileg stabilak voltak, növekedést mutattak a szubjektív jóllét területén a második mérés 
időpontjában, illetve azok, akik eredetileg magasabb jólléttel voltak jellemezhetők, idővel következetesen barátságosabbá, lelkiismeretesebbé, érzelmileg stabilabbá és extravertáltabbá váltak. A jövőbeli kutatásoknak érdemes ezért longitudinális adatgyújtést alkalmazva megvizsgálni a felvetett hipotéziseket a pszichológiai jóllét vonatkozásában is.

\section{Irodalom}

Abbott, R., Ploubidis, G., Huppert, F., Kuh, D., \& Groudace, T. (2010). An evaluation of the precision of measurement of Ryff's Psychological Well-Being Scales in a population sample. Social Indicators Research, 97(3), 357-373.

Abbott, R.A., Croudace, T.J., Ploubidis, G.B., Kuh, D., Richards, M., \& Huppert, F.A. (2008). The relationship between early personality and midlife psychological well-being: evidence from a UK birth cohort study. Social Psychiatry and Psychiatric Epidemiology, 43(9), 679-687.

Alarcon, G.M., Bowling, N.A., \& Khazon, S. (2013). Great expectations: A meta-analytic examination of optimism and hope. Personality and Individual Differences, 54(7), 821-827.

Andrews, F.M., \& McKennell, A.C. (1980). Measures of self-reported well-being: Their affective, cognitive and other components. Social Indicators Research, 8(2), 127-155.

Bierman, A., Fazio, E.M., \& Milkie, M.A. (2006). A multifaceted approach to the mental health advantage of the married: Assessing how explanations vary by outcome measure and unmarried group. Journal of Family Issues, 27(4), 554-582.

Carpara, G.V., Barbaranelli, C., Borgogni, L., \& Perugini, M. (1993). The „big five questionnaire": A new questionnaire to assess the five factor model. Personality and Individual Differences, 15(3), 281-288.

Carver, C.S., \& Scheier, M.F. (1981). Attention and self-regulation: A control-theory approach to human behavior. New York: Springer-Verlag

Carver, C.S., \& Scheier, M.F. (1990). Origins and functions of positive and negative affect: control-process view. Psychological Review, 97(1), 19-35.

Clarke, P.J., Marshall, V.W., Ryff, C.D., \& Rosenthal, C.J. (2000). Well-being in Canadian seniors: Findings from the Canadian Study of health and aging. Canadian Journal on Aging, 19(2), 139-159.

Costa, P.T., \& McCrae, R.R. (1980). Influences of extraversion and neuroticism on subjective well-being: happy and unhappy people. Journal of Personality and Social Psychology, 38(4), 668-678.

DeNeve, K.M., \& Cooper, H. (1998). The happy personality: A meta-analysis of 137 personality traits and subjective well-being. Psychological Bulletin, 124(2), 197-229.

Diener, E. (1984). Subjective well-being. Psychological Bulletin, 95(3), 542-575.

Ferguson, S.J., \& Goodwin, A.D. (2010). Optimism and well-being in older adults: The mediating role of social support and perceived control. International Journal of Aging and Human Development, 71(1), 43-68.

Gray, J.A. (1970). The psychophysiological basis of introversion-extraversion. Behaviour Research and Therapy, 8(3), 249-266.

Gray, J.A. (1991). Neural systems, emotion, and personality. In J. Madden IV (Ed.), Neurobiology of Learning, Emotion, and Affect (273-306). New York: Raven 
Gutiérrez, J.L.G., Jiménez B.M., Hernández, E.G. \& Puente, C.P. (2005). Personality and subjective well-being: big five correlates and demographic variables. Personality and Individual Differences, 38(7), 1561-1569.

Hayes, N., \& Joseph, S. (2003). Big 5 correlates of three measures of subjective well-being. Personality and Individual Differences, 34(4), 723-727.

Headey, B., \& Wearing, A. (1992). Understanding happiness: A theory of Subjective Well-being. Melbourne: Longman Cheshire

Ibironke, S.O., \& Donald, D.U. (2015). Personality factors, dispositional optimism and single parenting as predictors of psychological wellbeing among undergraduates. World Journal of Pharmacy and Pharmaceutical Sciences, 4(7), 196-212.

Inglehart, R. (1990). Culture shift in advanced industrial society. Princeton, NJ: Princeton University Press

Kafka, G. J., \& Kozma, A. (2002). The construct validity of Ryff's scales of psychological well-being and their relationship to measure of Subjective well-being. Social Indicators Research, 57(2), 171-190.

Karasawa, M., Curhan, K., Markus, H., Kitayama, S., Love, G., Radler, B., \& Ryff, C. (2011). Cultural perspectives on aging and well-being: A comparison of Japan and the United States. International Journal of Aging and Human Development, 73(1), 73-98.

Kleiman, E.M., Alexandra, M.C., Liu, R.T., Jager-Hyman, S.G., Choi, J.Y., \& Alloy, L.B. (2015). Optimism and well-being: a prospective multi-method and multi-dimensional examination of optimism as a resilience factor following the occurrence of stressful life events. Cognition E Emotion, Publishing online: 11 Nov, 2015. Doi: 10.1080/0269 9931.2015.1108284

Larsen, R.J., \& Ketelaar, T. (1989). Extraversion, neuroticism, and susceptibility to positive and negative mood induction procedures. Personality and Individual Differences, 10(12), 1221-1228.

Larsen, R.J., \& Ketelaar, T. (1991). Personality and susceptibility to positive and negative emotional states. Journal of Personality and Social Psychology, 61(1), 132-140.

Lauriola, M., \& Iani, L. (2015). Does positivity mediate the relation of extraversion and neuroticism with subjective happiness? PLOS ONE, 10(3), 1-16.

Lucas, R.E., Diener, E., \& Suh, E. (1996). Discriminant validity of well-being measures. Journal of Personality and Social Psychology, 71(3), 616-628.

Lucas, R.E., \& Fujita, F. (2000). Factors influencing the relation between extraversion and pleasant affect. Journal of Personality and Social Psychology, 79(6), 1039-1056.

Marks, N.F., \& Lambert, J.D. (1998). Marital status continuity and change among young and midlife adults: Longitudinal effects on psychological well-being. Journal of Family Issues, 19(6), 652-686.

McCrae, R.R., \& Costa, P.T. (1991). Adding liebe and arbeit: The full five-factor model and well-being. Personality and Social Psychology, 17(2), 227-232.

Michalos, A.C. (1991). Global report on student well-being. New York: Springer-Verlag

Myers, D.G. (1992). The pursuit of happiness: Who is happy - and why. New York: Morrow

$\mathrm{Ng}$, W. (2015). Processes Underlying Links to Subjective Well-being: Material Concerns, Autonomy, and Personality. Journal of Happiness Studies, 16(6), 1575-1591.

Oláh, A. (2005). Érzelmek, megküzdés és optimális élmény. Belső világunk megismerésének módszerei. Budapest: Trefort Kiadó

Oláh, A. (2012). A megküzdés szívárványszínei: a stresszkezeléstől a boldogság növeléséig. In M. Fülöp, \& É. Szabó (Szerk.), A pszichológia, mint társadalomtudomány (507-522). A 70 éves Hunyady György tiszteletére. Budapest: ELTE Eötvös Kiadó 
Rózsa, S., Kő, N., \& Oláh, A. (2006). Rekonstruálható-e a Big Five magyar mintán: A Carparaféle „Big Five Kérdőív” (BFQ) felnőtt változatának hazai adaptációja és nemzetközi összehasonlító elemzése. Magyar Pszichológiai Szemle, 26(1), 57-76.

Rusting, C.L. (1998). Personality, mood, and cognitive processing of emotional information: three conceptual frameworks. Psychological Bulletin, 124(2), 165-196.

Rusting, C.L., \& Larsen, R.J. (1997). Extraversion, neuroticism, and susceptibility to positive and negative affect: a test of two theoretical models. Personality and Individual Differences, 22(5), 607-612.

Ryan, R.M., \& Deci, E.L. (2001). On happiness and human potentials: a review of research on hedonic and eudaimonic well-being. Annual Review of Psychology, 52(1), 141-166.

Ryff, C.D. (1989a). Happiness is everything, or is it: Explorations on the meaning of psychological well-being. Journal of Personality and Social Psychology, 57(6), 1069-1081.

Ryff, C.D. (1989b). In the eye of the beholder: views of psychological well-being among middle-aged and older adults. Psychology and Aging, 4(2), 195-210.

Ryff, C.D. (2014). Psychological well-being revisited: Advances in science and practice. Psychoterapy and Psychosomatics, 83(1), 10-28.

Ryff, C.D., \& Keyes, C.L.M. (1995). The structure of psychological well-being revisited. Journal of Personality and Social Psychology, 69(4), 719-727.

Scheier, M.F., \& Carver, C.S. (1985). Optimism, coping and health: assessment and implications of generalized outcome expectancies. Health Psychology, 4(3), 219-247.

Schmutte, P.S., \& Ryff, C.D. (1997). Personality and well-being: Reexamining methods and meanings. Journal of Personality and Social Psychology, 73(3), 549-559.

Soto, C.J. (2015). Is happiness good for your personality? Concurrent and prospective relations of the Big Five with Subjective well-being. Journal of Personality, 83(1), 45-55.

Springer, K.W., Hauser, R.M., \& Freese, J. (2006). Bad news indeed for Ryff's six-factor model of well-being. Social Science Research, 35, 1120-1131.

Steel, P., Schmidt, J., \& Schultz, J. (2008). Refining the relationship between personality and subjective well-being. Psychological Bulletin, 134(1), 138-161.

Tellegen, A. (1985). Structures of mood and personality and their relevance to assessing anxiety, with an emphasis in self-report. In A.H. Tuma., \& J.D. Maser (Eds.), Anxiety and the Anxiety Disorders (681-706). Hillsdale, NJ: Erlbaum

Veenhoven, R. (1993). Happiness in nations. Rotterdam: Risbo

Wilson, W.R. (1967). Correlates of avowed happiness. Psychological Bulletin, 67(4), 294-306.

\section{Szerzói munkamegosztás}

Nagy Henriett: elméleti áttekintés, hipotézisalkotás, adatgyújtés megtervezése és lebonyolítása, az eredmények bemutatása, értelmezése. Gyurkovics Máté: statisztikai számítások, az eredmények bemutatása, értelmezése.

\section{Nyilatkozat érdekütközésról}

A szerzők ezúton kijelentik, hogy esetükben nem állnak fenn érdekütközések. 


\title{
The relationships between sociodemographic factors, big five, optimism and psychological well-being
}

\author{
NAGY, HENRIETT - GYURKOVICS, MÁTÉ
}

Background: The multidimensional model of psychological well-being (PWB) was originally proposed by Ryff in 1989. Empirical studies investigating the relationship of personality and psychological well-being have clearly shown that extraversion $(+)$, neuroticism $(-)$ and optimism (+) are related to well-being. Aims: We seek to answer two questions: (1) can personality predict psychological well-being after controlling for demographic variables? and (2) can optimism predict well-being after controlling for the effects of the Big Five dimensions? Method: In our cross-sectional study 314 persons (63.7\% women, mean age: 29.5 years, $\mathrm{SD}=10.96$ years) took part. As the first step of the study, we recorded sociodemographic data, then participants completed the Big Five Questionnaire, Scales of Psychological Well-Being and the Life Orientation Test. Results: We found that financial status, current place of residence and parent's education had a significant effect on psychological well-being. Dispositional optimism was found to be moderately correlated with PWB $(\mathrm{r}=.61, \mathrm{p}<.001)$, big five factors had a moderate at best association with psychological well-being $(r=|0,27|-|0,45|, p<.01)$. According to the binary logistic regression analyses the big five factors had a significant effect on PWB even after controlling for sociodemographic variables (Nagelkerke $\mathrm{R}^{2}=59.9 \% ; \chi^{2}(17)=156.35, p<.001$ ). Furthermore, they also demonstrate that optimism has a significant effect on one's psychological wellbeing $(\mathrm{OR}=4.32, \mathrm{p}=.014)$, and this effect is independent from that of the big five factors $\left(\right.$ Nagelkerke $\left.\mathrm{R}^{2}=61.7 \% ; \chi^{2}(18)=162.75 ; \mathrm{p}<.001 ; \Delta \chi^{2}(1)=6.39 ; \mathrm{p}=.011\right)$. Conclusions: Our findings are consistent with previous research suggesting that the big five factors play an important role in PWB. Furthermore, they also demonstrate that optimism has a significant effect on one's psychological well-being, and this effect is independent from that of the big five factors.

Keywords: psychological well-being, sociodemographic variables, personality, big five factors, optimism 